\title{
Silica Aerogel Improves the Biocompatibility in a Poly-e-Caprolactone Composite Used as a Tissue Engineering Scaffold
}

\author{
Jianhua Ge, ${ }^{1,2}$ Musen Li, ${ }^{1}$ Qingguo Zhang, ${ }^{2}$ Christopher Z. Yang, \\ Paul H. Wooley, ${ }^{2,3}$ Xiaofeng Chen, ${ }^{4}$ and Shang-You Yang ${ }^{2,3}$ \\ ${ }^{1}$ College of Material Science \& Engineering, Shandong University, Jinan 250061, China \\ ${ }^{2}$ Department of Biological Sciences, Wichita State University, 1845 N Fairmount Street, Wichita, KS 67260, USA \\ ${ }^{3}$ Orthopaedic Research Institute, Via Christi Health, Wichita, KS 67214, USA \\ ${ }^{4}$ School of Material Science \& Engineering, South China University of Technology, Guangzhou 510641, China
}

Correspondence should be addressed to Shang-You Yang; shang-you_yang@via-christi.org

Received 28 March 2013; Revised 17 June 2013; Accepted 18 June 2013

Academic Editor: Gonzalo Martínez-Barrera

Copyright (C) 2013 Jianhua Ge et al. This is an open access article distributed under the Creative Commons Attribution License, which permits unrestricted use, distribution, and reproduction in any medium, provided the original work is properly cited.

\begin{abstract}
Poly- $\varepsilon$-caprolactone (PCL) is a biodegradable polyester that has received great attentions in clinical and biomedical applications as sutures, drug delivery tool, and implantable scaffold material. Silica aerogel is a material composed of $\mathrm{SiO}_{2}$ that has excellent physical properties for use in drug release formulations and biomaterials for tissue engineering. The current study addresses a composite of silica aerogel with PCL as a potential bone scaffold material for bone tissue engineering. The biocompatibility evaluation of this composite indicates that the presence of silica aerogel effectively prevented any cytotoxic effects of the PCL membrane during extended tissue culture periods and improved the survival, attachment, and growth of 3T3 cells and primary mouse osteoblastic cells. The beneficial effect of silica aerogel may be due to neutralization of the acidic condition that develops during PCL degradation. Specifically, it appears that silica aerogel to PCL wt/wt ratio at $0.5: 1$ maintains a constant $\mathrm{pH}$ environment for up to 4 weeks and provides a better environment for cell growth.
\end{abstract}

\section{Introduction}

Poly- $\varepsilon$-caprolactone (PCL) is one of the polyester polymers that possess several advantages including benign biocompatibility, low cost, biodegradability, and easy fabrication. Previous studies have suggested that PCL was a good candidate biomaterial for cartilage tissue engineering in terms of cell attachment, proliferation, and matrix production [1-4]. Positive effects of PCL composites on osteoblasts when using as bone graft substitute have also been demonstrated [3, 5-7]. In addition, PCL has been investigated for reconstruction of many other tissues such as skin, nerve, and retina [8]. The major drawback to the use of PCL as tissue scaffold is the production of an acidic environment during the PCL degradation process, which may influence the local microenvironment and cell viability.
Aerogels are materials with extremely high porosity and a high surface area [9]. They are usually produced by supercritical extraction of a stable gel using sol-gel technology $[10,11]$. Aerogels have useful properties such as high heat insulation $[12,13]$, low refractive index $[14,15]$, and dielectric constant close to gas properties [16, 17]. For the past decade, aerogels have gained increased attention in the biomedical field as a potential tool for targeted drug delivery systems [18-20]. Silica aerogel is a material composed of $\mathrm{SiO}_{2}$ with physical properties that include (1) amorphous properties with extremely low bulk density $\left(0.003-0.35 \mathrm{~g} / \mathrm{cm}^{3}\right),(2)$ optical transparency that facilitates the identification of captured material(s) within the aerogel, (3) high thermal insulation, and (4) light weight. Silica aerogel exhibits a high surface area with a structure comprised of three-dimensional beaded connections of silica particles with several nanometers in diameter, forming 
uniform pore sizes of tens of nanometers in diameter [21]. Silica-based bioglass has been successfully used for bonefilling material in orthopedic surgery and dental care [2224]. Hench et al. [25] first reported the development of 45S5 Bioglass in 1971, which contained the following compositions: 45 wt. $\% \mathrm{SiO}_{2}, 24.5$ wt. $\% \mathrm{Na}_{2} \mathrm{O}, 24.5$ wt. $\% \mathrm{CaO}$, and 6 wt.\% $\mathrm{P}_{2} \mathrm{O}_{5}\left(46.1 \mathrm{SiO}_{2}, 24.4 \mathrm{Na}_{2} \mathrm{O}, 26.9 \mathrm{CaO}\right.$, and $\left.2.6 \mathrm{P}_{2} \mathrm{O}_{5} \mathrm{~mol} \%\right)$. Subsequently, various systems of silica bioglasses have been described for wide applications in regenerative medicine including bone graft substitutes [26-31]. Using a rat model, Sabri et al. tested the biocompatibility properties of a polyurea cross-linked silica aerogels implant as a potential biomaterial for biomedical applications [32].

Our long-term goal is to develop a biocompatible bone graft substitute with seeding cells. The current study will test our hypothesis that the addition of the basic silica aerogel in the composite scaffold can neutralize the acidic environment and promote cell survival and growth. Specifically, silica aerogel + PCL membranes were fabricated with various contents of silica aerogel, and in vitro tests were performed to evaluate their degradability, cell biocompatibility, and cytotoxicity.

\section{Materials and Methods}

2.1. Silica Aerogel/PCL Membranes Preparation. Silica aerogel was prepared as described previously [11]. In brief, $1 \mathrm{~mL}$ of silica sols ( $\mathrm{pH}=10$, Shanghai Hengxin Chemical Reagent Co., China) was mixed with $2 \mathrm{~mL}$ of ethanol. The mixture was stirred and heated at $50^{\circ} \mathrm{C}$ for 5 hours followed by addition of another $2 \mathrm{~mL}$ of ethanol to the mixture. The mixture was then heated at $60^{\circ} \mathrm{C}$ for $24 \mathrm{~h}$. After adding $0.4 \mathrm{~mL}$ of tetraethyl orthosilicate (TEOS) and $2 \mathrm{~mL}$ of ethanol, the mixture was further heated at $70^{\circ} \mathrm{C}$ for 48 hours. The pulverized silica aerogel was obtained at the end of the heating process.

The silica aerogel/PCL composite membranes were fabricated at silica aerogel to PCL (Mn 80000, Sigma-Aldrich Chemicals, St. Louis, MO) wt/wt ratios of $0: 1$ (sample A), 0.125: 1 (sample B), 0.25:1 (sample C), or 0.5:1 (sample D). Briefly, $1 \mathrm{~g}$ of PCL was dissolved in $10 \mathrm{~mL}$ of tetrahydrofuran (Sigma-Aldrich) followed by mixing silica aerogel powders. The mixture was then cast into petri dishes at room temperature. After evaporation of the solvent overnight at room temperature, the silica aerogel/PCL membranes were placed under vacuum for $5 \mathrm{~h}$ at room temperature to remove tetrahydrofuran residue.

\subsection{Determination of $p H$ Changes in Solutions Soaking Silica} Aerogel/PCL Membranes. The composite membrane pieces $(10 \mathrm{~mm} \times 5 \mathrm{~mm} \times 0.04 \mathrm{~mm})$ with various silica aerogel, PCL, ratios were immersed, respectively, in $5 \mathrm{~mL}$ of distilled water for up to 4 weeks. pH values of the immersion water from different samples were tested every 7 days using a $\mathrm{pH}$ meter (model AB15, Fisher Scientific).

2.3. Cell Cultures. The $3 \mathrm{~T} 3$ cells (ATCC, Manassas, VA) were cultured in Dulbecco's modified eagle's medium (DMEM) supplemented with $5 \%$ fetal bovine serum (FBS) (Invitrogen, Grand Island, NY), 2 mM glutamine (Invitrogen), $100 \mathrm{U} / \mathrm{mL}$ penicillin (Invitrogen), and $100 \mu \mathrm{g} / \mathrm{mL}$ streptomycin (Invitrogen) at $37^{\circ} \mathrm{C}$ with $5 \% \mathrm{CO}_{2}$ atmosphere.

Primary osteogenic cells were induced from mouse bone marrow mononuclear cells isolated by density centrifugation over Histopaque-1083 (Sigma-Aldrich, USA), as detailed previously $[33,34]$. The cells were cultured in complete media consisting of DMEM supplemented with 10\% FBS, $10 \mathrm{mM} \beta$ glycerol phosphate (Sigma-Aldrich), $10^{-4} \mathrm{M}$ L-ascorbic acid (Sigma-Aldrich), $10 \mathrm{nM}$ dexamethasone (Sigma-Aldrich), $2 \mathrm{mM}$ glutamine, $100 \mathrm{U} / \mathrm{mL}$ penicillin (Invitrogen), and $100 \mu \mathrm{g} / \mathrm{mL}$ streptomycin. Cells were subcultured when confluence and the 3rd passages of the cells were used for the biocompatibility studies. Over $90 \%$ of the induced osteoblastic cells were able to express alkaline phosphatase (ALP) and osteocalcin (established techniques in the lab, data not shown) $[34,35]$.

\subsection{Biocompatibility Evaluations on Cells with the Silica} Aerogel/PCL Membranes. At 90\% confluence, 3T3 cells or the primary osteoblastic cells were subcultured in each well of a 24-well plate at $10^{4}$ cells/well with the testing materials (in $16 \mathrm{~mm}$ diameter disc) for up to 7 days. Cells cultured without testing composite material were kept as nontreated controls. At day 4 or day 7, a cell proliferation assay (MTT assay) was performed as described previously [36]. Briefly, $100 \mu \mathrm{L}$ MTT (3-(4,5-dimethylthiazol-2-yl)-2,5-diphenyltetrazolium bromide, Aldrich-Sigma) at $5 \mathrm{mg} / \mathrm{mL}$ in PBS was added into each well for 6 hour incubation, followed by $10 \%$ sodium dodecyl sulfate (SDS) treatment at $37^{\circ} \mathrm{C}$ overnight. $200 \mu \mathrm{L}$ of supernatant from each well was transferred to a 96 -well plate the next day to read at $590 \mathrm{~nm}$ wavelength on a SpectraMax Plus 384 microplate spectrophotometer (Molecular Devices, Sunnyvale, CA). For cell viability estimation, the lactate dehydrogenase (LDH) assay was performed, using a CytoTox 96 Non-Radioactive Cytotoxicity Assay kit (Cat no. G1780, Promega, Madison, WI). LDH activity in the culture media and the lysed cells was, respectively, assayed by colorimetric reaction with the substrate provided in the kit. The optical density (OD) values were recorded spectrophotometrically at $490 \mathrm{~nm}$; the cell viability and cytotoxicity were calculated by relative medium LDH level over the cell lysis LDH as stated in the vendor's protocol.

2.5. Cytotoxicity Potential of the Eluted Solutions from the Silica Aerogel/PCL Membranes. Testing membranes $(10 \mathrm{~mm} \times$ $10 \mathrm{~mm}$ ) were immersed in $333 \mu \mathrm{L}$ culture medium in a sterile test tube at $37^{\circ} \mathrm{C}$. The culture medium was collected 24 hours later (as day 1 release medium), and the same amount $(333 \mu \mathrm{L})$ of fresh medium was added to the tube. The same procedure was repeated everyday to obtain day 2 to day 8 release media.

$3 \mathrm{~T} 3$ cells were seeded in a 96 -well plate at $10^{4} / 100 \mu \mathrm{L}$ medium/well for $24 \mathrm{~h}$ in an incubator $\left(37^{\circ} \mathrm{C}, 5 \% \mathrm{CO}_{2}\right.$ in air) before introduction of the membrane release media (100 $\mu \mathrm{L} /$ well). Fresh culture medium without release medium was used as a control. Cells were then incubated at $37^{\circ} \mathrm{C}$, $5 \% \mathrm{CO}_{2}$ for $72 \mathrm{~h}$, followed by adding $20 \mu \mathrm{L} \mathrm{MTT}(5 \mathrm{mg} / \mathrm{mL})$ in each well. The MTT was replaced after $6 \mathrm{~h}$ incubation by $200 \mu \mathrm{L}$ of $10 \%$ SDS, and the cells were incubated overnight 


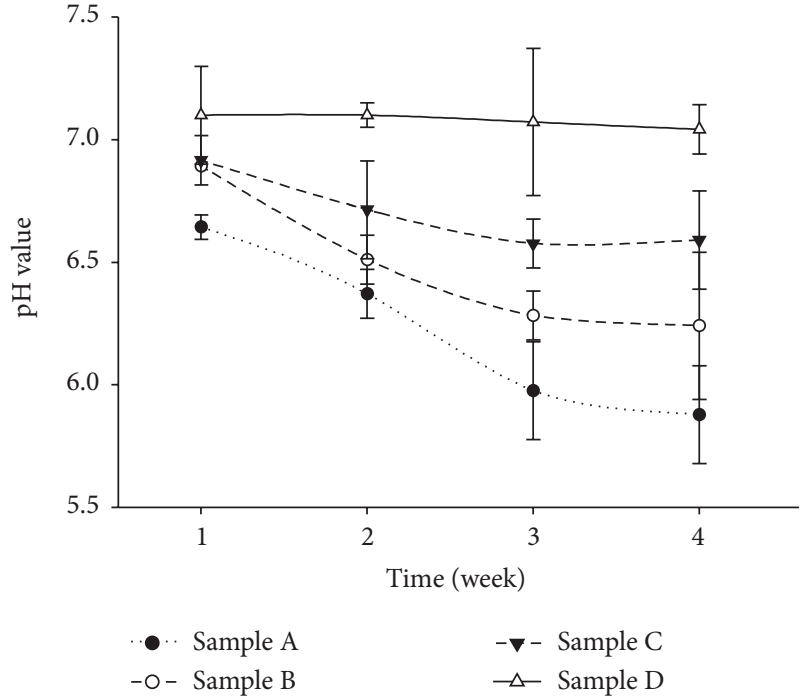

FIGURE 1: The $\mathrm{pH}$ values of the distilled water over the time (in weeks) with sample A (silica aerogel to PCL wt/wt ratio $0: 1$ ), sample B (silica aerogel to PCL $0.125: 1$ ), sample C (silica aerogel to PCL $0.25: 1$ ), and sample D (silica aerogel to PCL $0.5: 1)$. ${ }^{*} P<0.05$.

at $37^{\circ} \mathrm{C}, 5 \% \mathrm{CO}_{2}$. The next day, these 96 -well plates were read at a $590 \mathrm{~nm}$ wavelength on a microplate photospectrometer (Molecular Devices). The OD values were recorded for cytotoxicity index determination. Cytotoxicity index of the samples was calculated by normalizing the MTT assay values with the proliferation data of the nontreated cells:

Cytotoxicity Index

$$
=100-\left(\frac{\text { sample's OD value }}{\text { mean OD value of controls }} \times 100\right),
$$

while the cytotoxicity index would be 0 if the sample OD value/controls mean $O D$ value was larger than 0.7 , suggesting no cytotoxic influence.

2.6. Scanning Electron Microscope (SEM) Assessment. Primary osteoblastic cells at $10^{5} / \mathrm{mL}$ were cultured on the testing materials in a 24 -well plate at $37^{\circ} \mathrm{C}, 5 \% \mathrm{CO}_{2}$ for 4 days. The samples were then fixed in 1.5\% glutaraldehyde (Fisher Scientific, USA) and 2\% osmium tetroxide (Sigma-Aldrich, USA), followed by dehydration in series of ethanol. The samples were left air dry for 4 hours under a laminar flow hood before sputter coating with gold and observed using a S-2400 Hitachi scanning electron microscope at $15 \mathrm{kV}$.

2.7. Statistical Analysis. The results were expressed as arithmetic mean and standard deviation of six separate samples for each test and control group, with total of three independent experiments. Statistical analysis between groups was performed by single factor analysis of variance (ANOVA) test, with the LSD formula for post hoc multiple comparisons

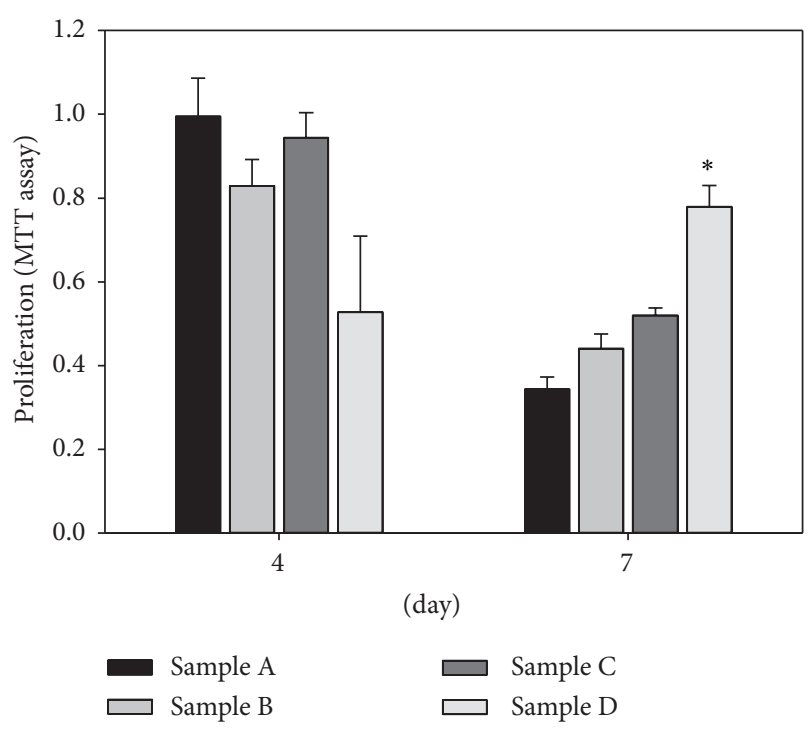

FIGURE 2: MTT assay was performed to assess the survival and proliferation of 3T3 cells when exposed to the testing materials (samples A-D). Significantly cell growth was observed in sample D (silica aerogel to PCL wt/wt ratio $0.5: 1)$ at day 7 in comparison with other groups $\left({ }^{*} \mathrm{P}<0.05\right)$.

(SPSS v16, Chicago, IL). A $P$ value of less than 0.05 was considered as significant difference.

\section{Results}

3.1. $p H$ Changes following Silica Aerogel/PCL Membranes Immersion in Distilled Water. Figure 1 summarizes the $\mathrm{pH}$ changes during the immersion test over a period of 4 weeks. The results clearly showed that an increase in the silica aerogel ratio in the composite correlated with the elevation of $\mathrm{pH}$. While the $\mathrm{pH}$ values of the distilled water immersed with samples $\mathrm{A}, \mathrm{B}$, and $\mathrm{C}$ progressively declined over the extended time period, the $\mathrm{SiO}_{2}-\mathrm{PCL}$ composite at 0.5:1 ratio (sample D) sustained in the water for up to 4 weeks without significant $\mathrm{pH}$ changes, and the data were statistically significant at 2,3 , and 4 weeks when compared to samples A and B $(P<0.05)$.

3.2. Biocompatibility of Silica Aerogel/PCL Membranes. The MTT assay indicated a level of cell growth inhibition during the early days of culture with the high silica aerogel composite (sample D), in comparison with other testing materials (Figure 2). However, it appeared that increasing the $\mathrm{SiO}_{2}$ ratios (samples B-D) positively correlated with the cell survival at the 7 -day cultures $(P<0.05$, Figure 2$)$. LDH assay on the primary osteoblastic cell cultures clearly showed improved cell survival when exposed to the membranes with higher silica aerogel ratios $(P<0.05$, Figure 3$)$. The SEM observations correlated with the results of the proliferation and cell survival assays in that significantly more primary osteoblastic cells were attached on the surface of sample D compared to those on samples A and B after 4-day culture $(P<0.05$, Figure 4$)$. 


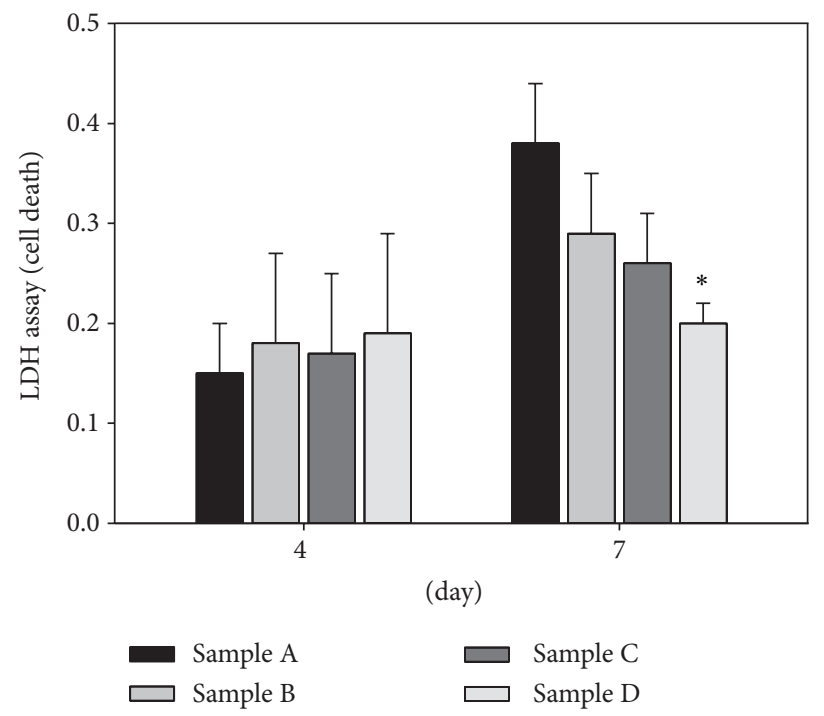

FIGURE 3: LDH assay was performed to evaluate the viability of the primary osteoblastic cells when exposed to the testing materials (samples A-D). While the cell death rate was low on all the groups at early days, elevated cell death was observed on samples A to C after 7-day culture except in the sample D group $\left({ }^{*} P<0.05\right)$.

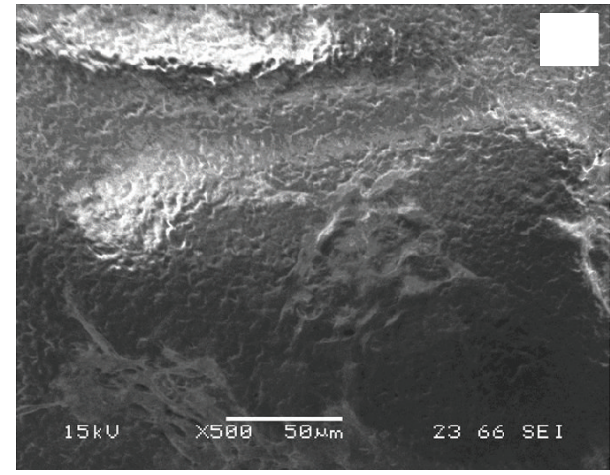

(a)

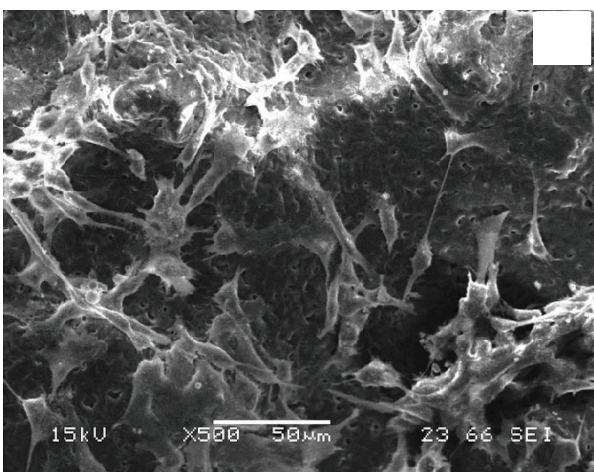

(c)

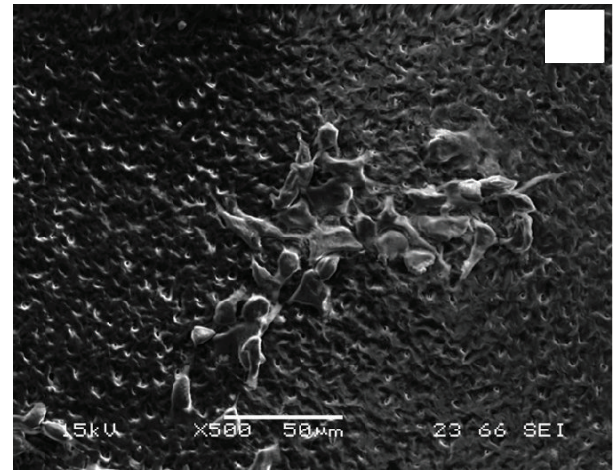

(b)

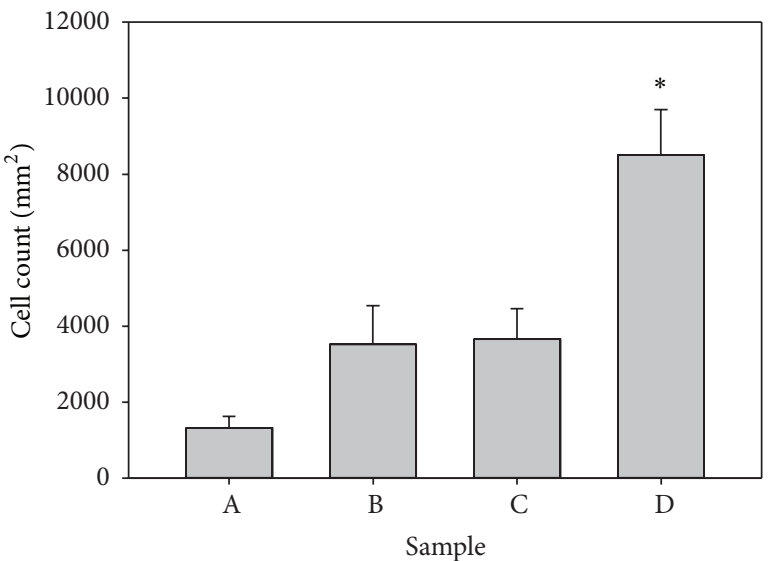

(d)

FIGURE 4: Representative SEM images of the primary osteoblastic cells cultured on the testing materials for 4 days: panel (a): sample A, panel (b): sample C, and panel (c): sample D. Panel (d) summarizes the cell numbers per $\mathrm{mm}^{2}$ membrane on each group, using a computerized image analysis system $\left({ }^{*} P<0.05\right)$. 
3.3. Cytotoxicity Effects of the Elution Products from the Silica Aerogel/PCL Membranes. MMT-based cytotoxicity assays were performed to assess the influence of the release media from the composite materials on the viability and growth of 3T3 cells. While there were no cytotoxic effects of the testing materials at the first 4 days elution, media from samples A, B, and $\mathrm{C}$ started to inhibit the cell growth after the 5-day immersion (Figure 5). However, the media from sample D (high $\mathrm{SiO}_{2}$ to PCL ratio membrane) immersion remained nontoxic for at least 8 days $(P<0.05$, Figure 5$)$.

\section{Discussion}

When developing a biomaterial scaffold for tissue engineering, it is desirable that the local microenvironment be maintained at $\mathrm{pH}$ 7.2-7.4. Since the acidic degradation product of PCL restrains the growth of cells or tissues, we hypothesize that addition of silica aerogel to PCL to form a PCL-silica aerogel composite material may neutralize the acidic condition that results from degradation of PCL and thus optimize the tissue repair microenvironment to allow cell growth and tissue regeneration. The data in this experiment is consistent with our hypothesis, showing that an increase in the ratio of $\mathrm{SiO}_{2}$ resulted in an elevation and stabilization of the environmental $\mathrm{pH}$, particularly for a silica aerogel to $\mathrm{PCL} w \mathrm{wt} / \mathrm{wt}$ ratio of $0.5: 1$.

In vitro assays were performed in this study to evaluate the biocompatibility of the silica aerogel-PCL membranes. NIH3T3 cells are standard fibroblastic cells which represent the most common cells in various connective tissues and have been broadly used for in vitro determination of general biocompatibility of potential biomaterials, including in bone scaffold research [31,37]. Primary osteoblastic cells were also used as a targeted cell type for bone graft substitutes. It is noteworthy that the presence of silica aerogel decreased the proliferation of the cells on the membranes during the early culture period, but the division rate of cells on the membranes recovered quickly and improved with the increase of silica aerogel amounts in the composite membranes. PCL, as one of the most popular synthetic polymers in tissue engineering and regenerative medicine, appears to be biocompatible yet not very intrinsic osteoinductive by itself $[34,38,39]$. In the current study, significant cell cytotoxicity was found in cultures on PCL alone and the lower ratios of $\mathrm{SiO}_{2}$ composite starting around day 5, suggesting that a suboptimal environment such as lower $\mathrm{pH}$ for cell survival was developed at this stage. However, cell viability and proliferation on the sample with a high ratio of $\mathrm{SiO}_{2}$ were maintained without overt cytotoxicity. It is apparent that the acidic degradation products of PCL were responsible for the inhibition of the cell growth, since the cell viability of PCL alone was approximately half of the values compared to the nonmaterial controls (Figure 2). The presence of silica aerogel neutralized the acidic condition and maintained the appropriate growth of cells. SEM revealed a significantly larger number of cells growing on the surface of sample D (Figure 4(c)). Cell quantification indicated that the cell attachment correlated with the increase of $\mathrm{SiO}_{2}$ ratios in the composite membranes.

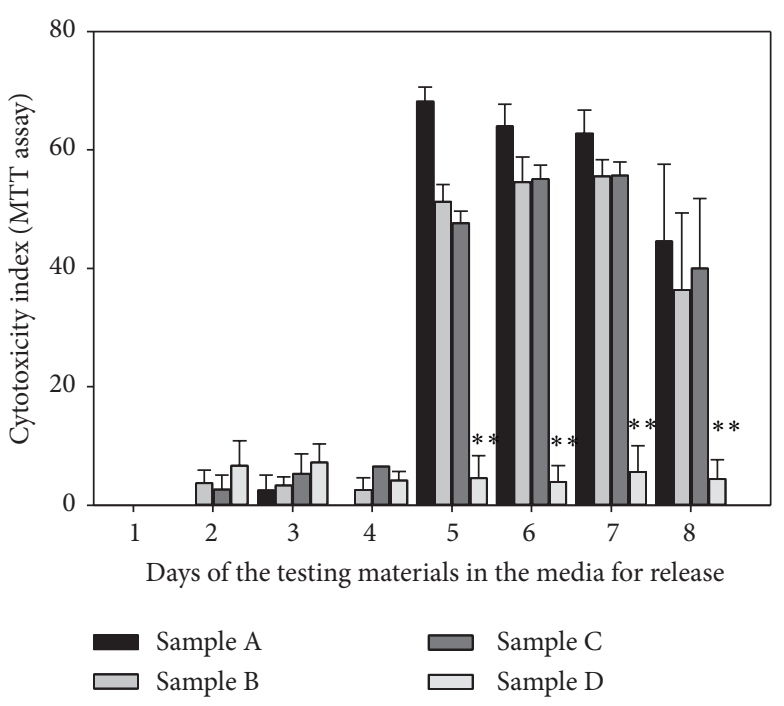

FIGURE 5: Cytotoxicity index was calculated based on MTT assay values to assess the cytotoxic influence of the release product from the testing materials (see Section 2 for calculation formula). Delayed cytotoxic effects were obvious on the texting samples except sample $\mathrm{D}\left({ }^{* *} P<0.01\right)$.

\section{Conclusions}

The data suggest that the presence of silica aerogel in the silica aeregel/PCL composite may inhibit the cell growth to a minor extent during the initial culture period, but neutralization of the acidic condition at the extended culture period is beneficial in maintaining and stimulating the ultimate cell survival and growth. The study provides intriguing information of the silica aerogel/PCL composite, and further investigation is underway to characterize its properties in animal models for bone and cartilage tissue repair/engineering, as well as the cellular and molecular mechanisms that may be involved in the regulation of the cell survival and proliferation under the presence of the biomaterial components.

\section{Conflict of Interests}

None of the authors has conflict of interests to disclose on this work. Dr. Paul H. Wooley is a consultant to the legal representatives of DePuy, Inc., who received no financial benefit for this service.

\section{Acknowledgments}

The work was partially supported by grants from the National Science Funds of China (51072055, 50830101, and CB606204), the Science Funds of Shandong Province (BS2010YY020, ZR2009FM023), and funds from the Orthopaedic Research Institute, Via Christi Wichita Hospitals, Inc. Authors wish to thank Ms. Zheng Song and Dr. Steve Miller for their excellent technical assistance and guidance. 


\section{References}

[1] R. Izquierdo, N. Garcia-Giralt, M. T. Rodriguez et al., "Biodegradable PCL scaffolds with an interconnected spherical pore network for tissue engineering," Journal of Biomedical Materials Research A, vol. 85, no. 1, pp. 25-35, 2008.

[2] J. M. Kemppainen and S. J. Hollister, "Differential effects of designed scaffold permeability on chondrogenesis by chondrocytes and bone marrow stromal cells," Biomaterials, vol. 31, no. 2, pp. 279-287, 2010.

[3] H. W. Kim, J. C. Knowles, and H. E. Kim, "Hydroxyapatite/ poly( $\varepsilon$-caprolactone) composite coatings on hydroxyapatite porous bone scaffold for drug delivery," Biomaterials, vol. 25, no. 7-8, pp. 1279-1287, 2004.

[4] W. J. Li, R. Tuli, C. Okafor et al., "A three-dimensional nanofibrous scaffold for cartilage tissue engineering using human mesenchymal stem cells," Biomaterials, vol. 26, no. 6, pp. 599609, 2005.

[5] L. Calandrelli, B. Immirzi, M. Malinconico et al., "Natural and synthetic hydroxyapatite filled PCL: mechanical properties and biocompatibility analysis," Journal of Bioactive and Compatible Polymers, vol. 19, no. 4, pp. 301-313, 2004.

[6] S. C. Rizzi, D. J. Heath, A. G. A. Coombes, N. Bock, M. Textor, and S. Downes, "Biodegradable polymer/hydroxyapatite composites: surface analysis and initial attachment of human osteoblasts," Journal of Biomedical Materials Research, vol. 55, no. 4, pp. 475-486, 2001.

[7] H. Yu, P. J. VandeVord, L. Mao, H. W. Matthew, P. H. Wooley, and S. Y. Yang, "Improved tissue-engineered bone regeneration by endothelial cell mediated vascularization," Biomaterials, vol. 30, no. 4, pp. 508-517, 2009.

[8] L. Ghasemi-Mobarakeh, M. P. Prabhakaran, M. Morshed, M. H. Nasr-Esfahani, and S. Ramakrishna, "Bio-functionalized PCL nanofibrous scaffolds for nerve tissue engineering," Materials Science and Engineering C, vol. 30, no. 8, pp. 1129-1136, 2010.

[9] H. Ren and L. Zhang, "In situ growth approach for preparation of Au nanoparticle-doped silica aerogel," Colloids and Surfaces A, vol. 372, no. 1-3, pp. 98-101, 2010.

[10] M. Alnaief and I. Smirnova, "In situ production of spherical aerogel microparticles," Journal of Supercritical Fluids, vol. 55, no. 3, pp. 1118-1123, 2011.

[11] J. Ge, Y. Z. Zhang, M. Li, and L. Song, "Research of bioactive PLGA tissue engineering materials processed by sol-gel method," Polymeric Materials Science and Engineering, vol. 27, no. 10, pp. 169-172, 2011.

[12] W. C. Ackerman, M. Vlachos, S. Rouanet, and J. Fruendt, "Use of surface treated aerogels derived from various silica precursors in translucent insulation panels," Journal of Non-Crystalline Solids, vol. 285, no. 1-3, pp. 264-271, 2001.

[13] A. Abu Obaid, S. Andersen, J. W. Gillespie Jr., R. Vaidyanathan, and A. Studley, "Investigation of thermal and acoustic performance of aerogel-based glass fiber composites," in Proceedings of the International SAMPE Symposium and Exhibition, pp. 22792290, May 2005.

[14] N. D. Hegde and A. V. Rao, "Effect of processing temperature on gelation and physical properties of low density TEOS based silica aerogels," Journal of Sol-Gel Science and Technology, vol. 38, no. 1, pp. 55-61, 2006.

[15] E. J. Lerner, "Less is more with aerogels," Industrial Physicist, vol. 10, no. 5, pp. 26-30, 2004.

[16] H. Fan, H. R. Bentley, K. R. Kathan, P. Clem, Y. Lu, and C. J. Brinker, "Self-assembled aerogel-like low dielectric constant films," Journal of Non-Crystalline Solids, vol. 285, no. 1-3, pp. 7983, 2001.

[17] G. S. Kim and S. H. Hyun, "Synthesis and characterization of silica aerogel films for inter-metal dielectrics via ambient drying," Thin Solid Films, vol. 460, no. 1-2, pp. 190-200, 2004.

[18] M. Alnaief and I. Smirnova, "Effect of surface functionalization of silica aerogel on their adsorptive and release properties," Journal of Non-Crystalline Solids, vol. 356, no. 33-34, pp. 1644-1649, 2010.

[19] I. Smirnova, S. Suttiruengwong, and W. Arlt, "Feasibility study of hydrophilic and hydrophobic silica aerogels as drug delivery systems," Journal of Non-Crystalline Solids, vol. 350, pp. 54-60, 2004.

[20] I. Smirnova, J. Mamic, and W. Arlt, "Adsorption of drugs on silica aerogels," Langmuir, vol. 19, no. 20, pp. 8521-8525, 2003.

[21] S. Sakka, "Application of sol-gel technolgy," in Handbook of SolGel Science and Technology, pp. 1-138, Kluwer Academic, New York, NY, USA, 2005.

[22] Z. Jia, J. Zhang, C. Jia, J. Nie, and K. Chu, "Preparation and characterization of mechanical properties of carbon nanotube/ 45S5Bioglass composites for biologic applications," Materials Science and Engineering A, vol. 528, no. 3, pp. 1553-1557, 2011.

[23] H. R. Stanley, M. B. Hall, A. E. Clark, C. J. King III, L. L. Hench, and J. J. Berte, "Using 45S5 bioglass cones as endosseous ridge maintenance implants to prevent alveolar ridge resorption: a 5year evaluation," International Journal of Oral and Maxillofacial Implants, vol. 12, no. 1, pp. 95-105, 1997.

[24] I. D. Xynos, M. V. J. Hukkanen, J. J. Batten, L. D. Buttery, L. L. Hench, and J. M. Polak, "Bioglass 45S5 stimulates osteoblast turnover and enhances bone formation in vitro: implications and applications for bone tissue engineering," Calcified Tissue International, vol. 67, no. 4, pp. 321-329, 2000.

[25] L. L. Hench, R. J. Splinter, W. C. Allen, and T. K. Greenlee, "Bonding mechanisms at the interface of ceramic prosthetic materials," Journal of Biomedical Materials Research, vol. 5, no. 6, pp. 117-141, 1972.

[26] A. L. Andrade, D. M. Souza, W. A. Vasconcellos, R. V. Ferreira, and R. Z. Domingues, "Tetracycline and/or hydrocortisone incorporation and release by bioactive glasses compounds," Journal of Non-Crystalline Solids, vol. 355, no. 13, pp. 811-816, 2009.

[27] M. Corno and A. Pedone, "Vibrational features of phosphosilicate glasses: periodic B3LYP simulations," Chemical Physics Letters, vol. 476, no. 4-6, pp. 218-222, 2009.

[28] G. Jiang, M. E. Evans, I. A. Jones, C. D. Rudd, C. A. Scotchford, and G. S. Walker, "Preparation of poly( $\varepsilon$-caprolactone)/continuous bioglass fibre composite using monomer transfer moulding for bone implant," Biomaterials, vol. 26, no. 15, pp. 22812288, 2005.

[29] P. P. Lopes, B. J. M. L. Ferreira, N. A. F. Almeida, M. C. Fredel, M. H. V. Fernandes, and R. N. Correia, "Preparation and study of in vitro bioactivity of PMMA-co-EHA composites filled with a $\mathrm{Ca}_{3}\left(\mathrm{PO}_{4}\right)_{2}-\mathrm{SiO}_{2}-\mathrm{MgO}$ glass," Materials Science and Engineering C, vol. 28, no. 4, pp. 572-577, 2008.

[30] S. N. Salama, H. Darwish, and H. A. Abo-Mosallam, "HA forming ability of some glass-ceramics of the $\mathrm{CaMgSi}_{2} \mathrm{O}_{6}$ $\mathrm{Ca}_{5}\left(\mathrm{PO}_{4}\right)_{3} \mathrm{~F}-\mathrm{CaAl}_{2} \mathrm{SiO}_{6}$ system," Ceramics International, vol. 32, no. 4, pp. 357-364, 2006.

[31] Y. Zhou, H. Li, K. Lin, W. Zhai, W. Gu, and J. Chang, "Effect of heat treatment on the properties of $\mathrm{SiO}_{2}-\mathrm{CaO}-\mathrm{MgO}-\mathrm{P}_{2} \mathrm{O}_{5}$ bioactive glasses.," Journal of Materials Science Materials in Medicine, vol. 23, no. 9, pp. 2101-2108, 2012. 
[32] F. Sabri, J. D. Boughter Jr., D. Gerth et al., "Histological evaluation of the biocompatibility of polyurea crosslinked silica aerogel implants in a rat model: a pilot study," PLOS ONE, vol. 7, no. 12, Article ID e50686, 2012.

[33] Y. Jiang, T. Jia, W. Gong, P. H. Wooley, and S. Y. Yang, “Titanium particle-challenged osteoblasts promote osteoclastogenesis and osteolysis in a murine model of periprosthestic osteolysis," Acta Biomaterialia, vol. 9, no. 7, pp. 7564-7572, 2013.

[34] H. Yu, P. H. Wooley, and S. Yang, "Biocompatibility of poly-caprolactone-hydroxyapatite composite on mouse bone marrow-derived osteoblasts and endothelial cells," Journal of Orthopaedic Surgery and Research, vol. 4, no. 1, article 5, 2009.

[35] Y. Jiang, T. Jia, W. Gong, P. H. Wooley, and S.-Y. Yang, "Effects of Ti, PMMA, UHMWPE, and Co-Cr wear particles on differentiation and functions of bone marrow stromal cells," Journal of Biomedical Materials Research A, 2013.

[36] H. L. Wamocha, H. E. Misak, Z. Song et al., "Cytotoxicity of release products from magnetic nanocomposites in targeted drug delivery," Journal of Biomaterials Applications, vol. 27, no. 6, pp. 661-667, 2013.

[37] K. T. Shalumon, K. H. Anulekha, K. P. Chennazhi, H. Tamura, S. V. Nair, and R. Jayakumar, "Fabrication of chitosan/ poly(caprolactone) nanofibrous scaffold for bone and skin tissue engineering," International Journal of Biological Macromolecules, vol. 48, no. 4, pp. 571-576, 2011.

[38] N. S. Binulal, M. Deepthy, N. Selvamurugan et al., "Role of nanofibrous poly(caprolactone) scaffolds in human mesenchymal stem cell attachment and spreading for in vitro bone tissue engineering-response to osteogenic regulators," Tissue Engineering A, vol. 16, no. 2, pp. 393-404, 2010.

[39] A. Polini, D. Pisignano, M. Parodi, R. Quarto, and S. Scaglione, "Osteoinduction of human mesenchymal stem cells by bioactive composite scaffolds without supplemental osteogenic growth factors," PLoS ONE, vol. 6, no. 10, Article ID e26211, 2011. 

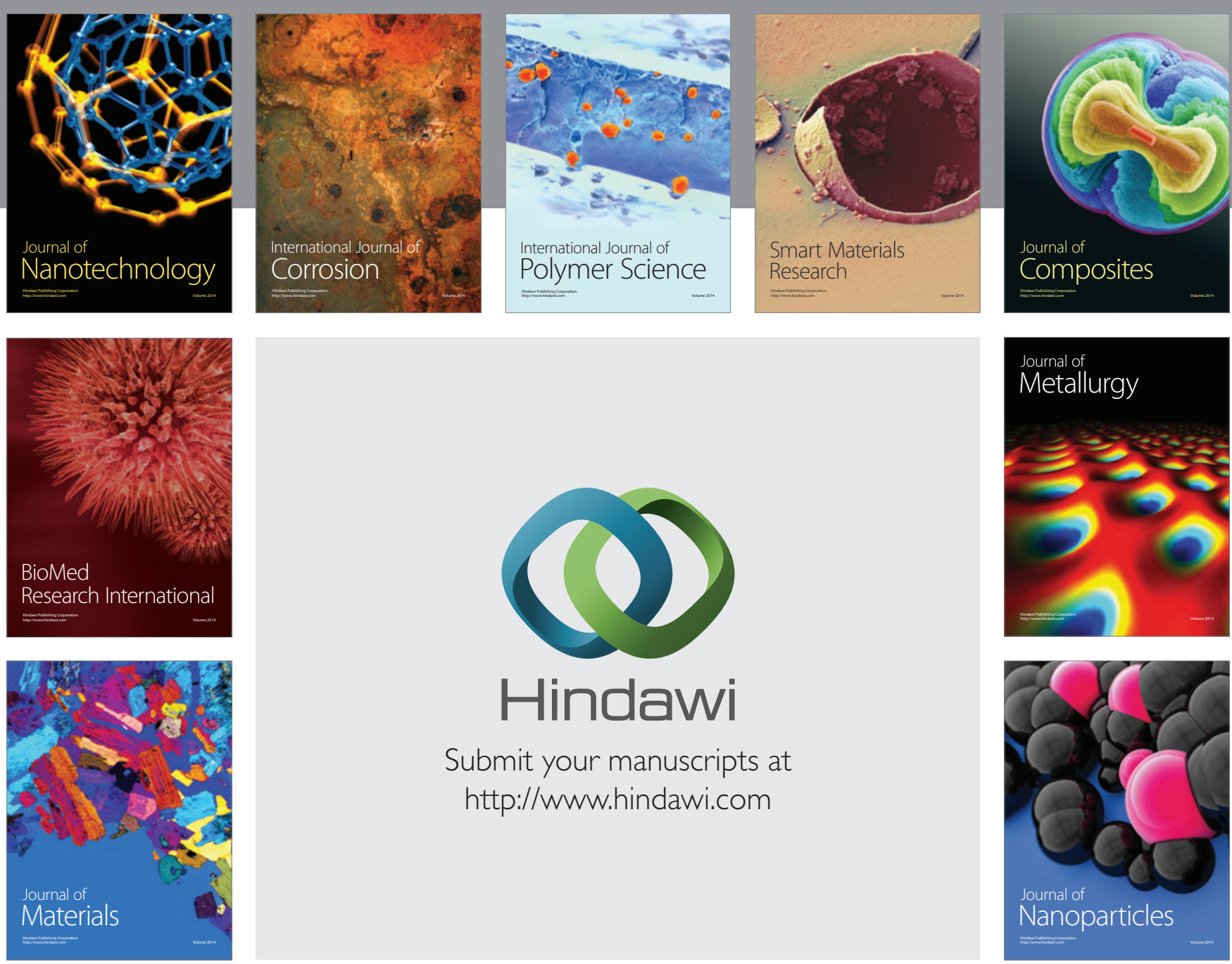

Submit your manuscripts at http://www.hindawi.com
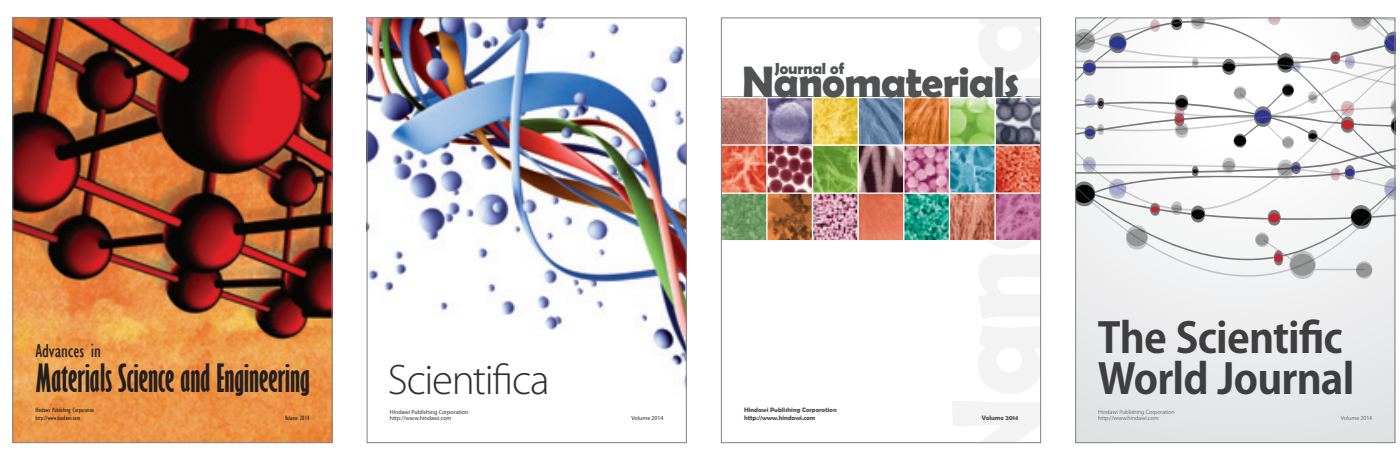

\section{The Scientific World Journal}
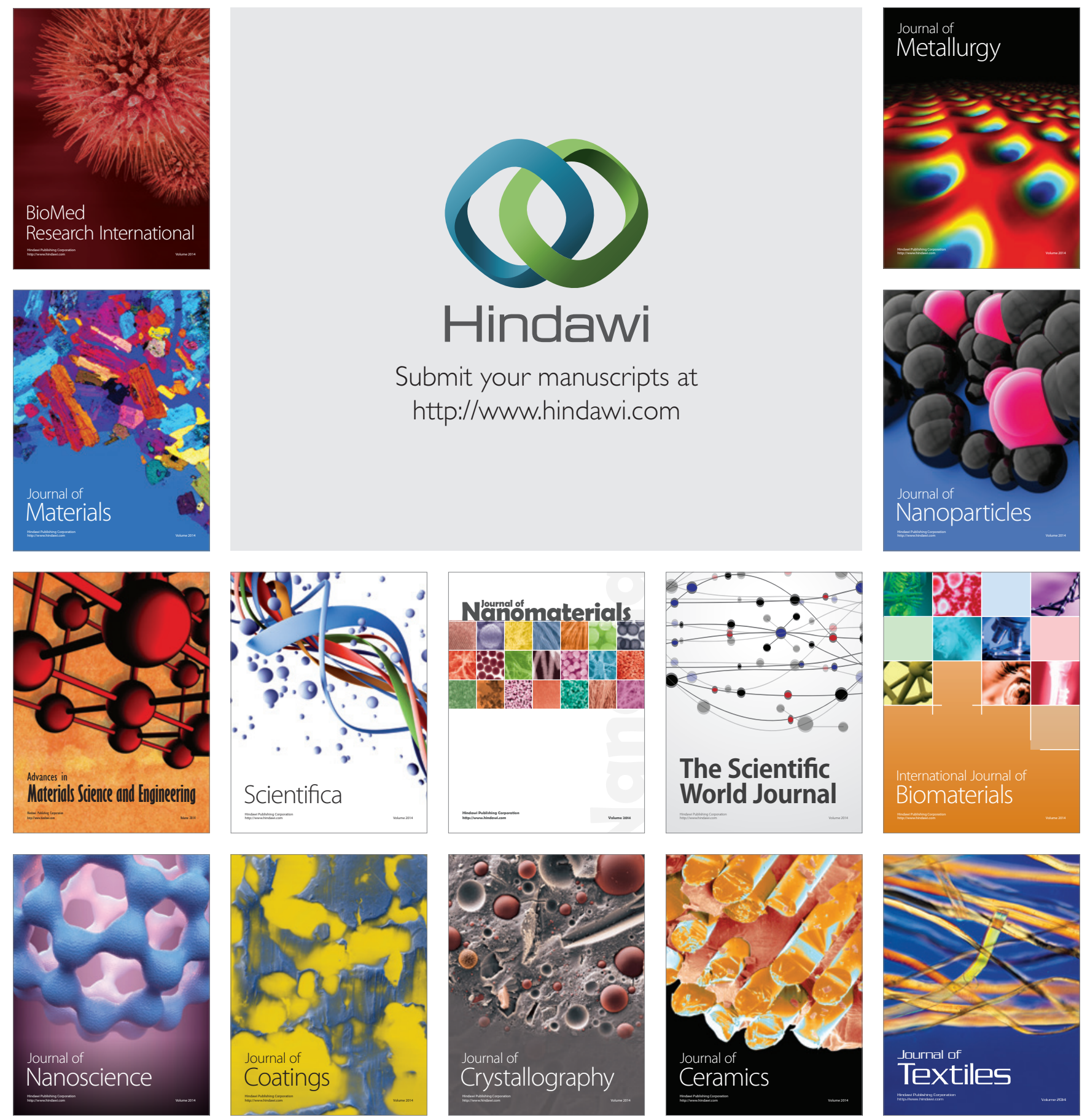